\title{
Managing livelihood risks: Income diversification and the livelihood strategies of households in pastoral settlements in Isiolo County, Kenya
}

\author{
Gargule Andrew Achiba(i)
}

\begin{abstract}
Research in northern Kenya presents evidence that livestock herding remains the most important income activity for households in pastoral settlements, even though non-livestock income activities constitute a significant proportion of household income. This paper explores the socio-economic determinants of pastoral income diversification using rural household data collected from three pastoral settlement in Isiolo County, northern Kenya. This study is concerned with the patterns and determinants of participation in non-pastoral income-earning activities (NPIs), including emerging household strategies and their impact on pastoral livestock production with particular reference to household dependence on livestock income. The results show that the intensity and proportion of NPIs in household incomes are determined by household demographic factors and mobility status. This study concludes that the increase in NPIs that accompanies pastoral livestock production points to the growing importance of livelihood security derived from both managing pastoral livestock production risks and optimizing incentives for non-livestock livelihoods. This finding implies that NPIs are not a substitute for pastoral livelihood, at least not as the base livelihood, in the study area.
\end{abstract}

Keywords: Kenya, Pastoralism, Income diversification, Arid and semi-arid lands

\section{Introduction}

Livelihood diversification and transition in rural Africa have been extensively studied in recent times (Barrett et al. 2001a, b; Ellis 1998, 2000, 2005; Carswell 2002). Many of these studies have focused on drivers and trends in income diversification among rural households, including a focus on constraints and incentives in rural Africa (Barrett et al. 2005; Smith et al. 2001). Some studies have also focused on livelihood diversification in the context of planned government settlement programmes (Chimhowu and Hulme 2006). Within this burgeoning interest in livelihood diversification is a large body of research dealing with the livelihood diversification of pastoral livestock keepers in marginal environments, such as the arid and semi-arid lands (ASALs) of East Africa (Ellis 2000; Davies 1993; Little et al. 2001a, b; Barrett et al.

Correspondence: gargule.achiba@cde.unibe.ch

Centre for Development and Environment, Universitat Bern, Hallerstrasse 10 3012, Bern, Switzerland 2001a, b, McCabe 2003; McCabe et al. 2014). In the context of pastoral herders, livelihood diversification is seen as an increasingly important risk management strategy by pastoral herders (Little et al. 2001a, b; Deng 2010) facing hardships in their livelihoods due to a host of challenges, including resource competition and conflict, droughts and population pressure (Fratkin 2013; Fratkin 1992; McCabe 2003; Desta and Coppock 2004). The debates regarding livelihood changes in the East African ASALs through non-livestock income activities show a remarkable tendency to miscast pastoral income diversification as an exit from pastoralism (Little et al. 2008).

In Kenya's ASALs, where the discontinuous variability of resources constrains the viability and productivity of other forms of livelihoods, pastoral livestock production is a critical component of household survival, as it is the dominant source of income and employment (Headey et al. 2012; Catley et al. 2013). The strategy of making a productive livelihood in the ASALs requires pastoralists

\section{Springer Open}

(c) The Author(s). 2018 Open Access This article is distributed under the terms of the Creative Commons Attribution 4.0 International License (http://creativecommons.org/licenses/by/4.0/), which permits unrestricted use, distribution, and reproduction in any medium, provided you give appropriate credit to the original author(s) and the source, provide a link to the Creative Commons license, and indicate if changes were made. 
to raise a minimum viable herd size and set of resources, a threshold below which survival on pastoralism becomes difficult (Lybbert et. al. "Pastoral risk and wealthdifferentiated herd accumulation patterns in Southern Ethiopia" unpublished). This means that maintaining an optimal balance between variable resources to meet livelihood needs remains a key objective among pastoral households (Hesse 2006).

Climatic variability and challenges posed by climate change are also running themes in studies on pastoral livelihood diversification. Consequently, diversification as applied to pastoralists has long been discussed, focusing specifically on the constraints posed by climatic risks (Blackwell 2010; McCabe et al. 2010; Speranza et al. 2008; Little et al. 2009), food security stress as a result of population pressure on natural resources (Hussein and Nelson 1998; Coppock 2016; Schmidt and Pearson 2016; Galvin et al. 2015; Nyberg et al. 2015) and the loss of common property resources (Coppock 2016; Coppock et al. 2015; Ensminger and Rutten 1991).

Ultimately, livelihood diversification in the ASALs serves to better manage risks and improve welfare (Little et al. 2001a, b) and may serve other purposes, such as improved nutrition (McCabe et al. 2014; Fratkin and Mearns 2003; Galvin et al. 1994). However, fewer studies have focused on how traditional livestock livelihoods evolve in response to the reported growth in the intensity of non-livestock income activities and what the implication of this evolution may be for the degree of household dependence on livestock. Despite the importance of household dependence on livestock in the ASALs, much remains unknown about how this dependence on livestock is changing in response to the growing importance of non-livestock livelihoods.

The present paper contributes to the existing knowledge gap by focusing on pastoral income diversification and its impact on dependence on livestock among pastoralist households in the midst of livelihood transition in northern Kenya. To do this, trends in the diversification strategies of different groups of households in pastoral settlements ${ }^{1}$ will be compared in Isiolo County in northern Kenya. This investigation is important for several reasons. First, approximately three million people in northern Kenya's ASALs depend on livestock for more than two thirds of their income (Chantarat et al. 2013). Thus, pastoral livestock wealth is an important component of the household economy and is crucial for food security; thus livestock development has been a central policy of the post-Independence government for decades.

Second, income diversification in the ASALs is not a recent phenomenon, and pastoral livestock resources are reported to have declined as a result of a combination of the complex synergetic factors of increased pressure on pastoral common pool resources, climate change and associated drought risks, all leading to a loss of adaptive capacity for pastoral households (Lambin et al. 2003). Moreover, much less is known about the impact of non-livestock livelihoods on pastoral dependence on livestock. Finally, understanding income diversification is important in the context of African drylands where livelihood risks are increasing pressure on pastoral livelihoods.

\section{Theoretical and empirical literature: An overview}

Broadly defined, diversification is "the process by which rural families construct a diverse portfolio of activities and social support capabilities in their struggle for survival and in order to improve their standards of living" (Ellis 1998, p. 4). According to Ellis, this process encompasses household cash income, in-kind transfers, social institutions and networks and benefits derived from social services. Functionally, this conception of diversification is linked to the drivers and consequent household strategies to engage in additional income pursuits outside of the primary livelihood activity. However, income diversification does not necessarily constitute livelihood diversification and vice versa (Ellis 1998). This study is concerned with income diversification in the context of pastoralism and follows the definition of pastoral diversification provided by Little et al. (2001a, b):

“...pursuit of any non-pastoral income-earning activity, whether in rural or urban areas. This definition includes (1) any form of trading occupation (for example, selling milk, firewood, animals, or other products); (2) wage employment, both local and outside the area, including working as a hired herder, farm worker, and migrant labourer; (3) retail shop activities; (4) rental property ownership and sales; (5) gathering and selling wild products (for example, Gum-Arabica, firewood, or medicinal plants); and (6) farming (both for subsistence and cash incomes)." (Little et al.

2001a, b, p. 403)

Little's approach views livelihood diversification as a set of strategies that herders use to pursue accumulation and investment by taking advantage of opportunities in the growth of communication and infrastructure, markets and other services identified as "pull factors". According to this conception by Little et al. (2001a, b), poor herders are "pushed into diversification" out of necessity and the need to survive. Thus, this conception looks at pastoral livelihood diversification by distinguishing three different sets of variables that can be used to explain herder decisions and strategies to diversify (see Figure 1). Thus, diversification strategy is centred around taking advantage of the availability, accessibility and benefits derived from conditional and opportunity 
Conditioning Variables

External income transfers (food aid,

social protection)

Human population density

Per capita livestock holding and

distribution

Open rangeland per capita

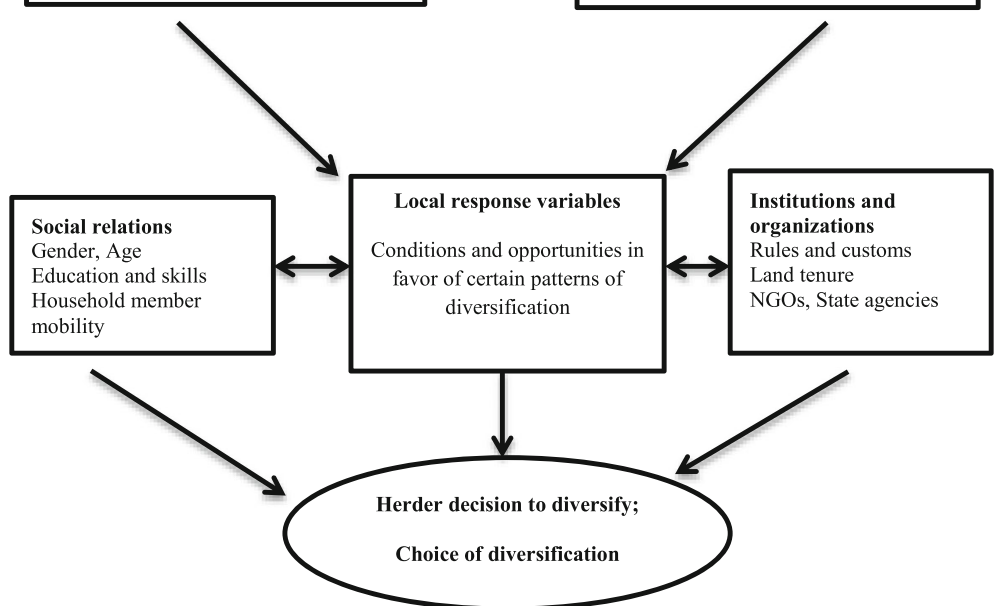

Opportunity Variables

Distance to cities and market town

nfrastructure and services

Education

Figure 1 A framework for pastoral livelihood diversification. After Little et al. (2001b, p. 392)

variables while managing opportunities and constraints imposed by local response variables.

This approach is also closely aligned with the nuances and complexities that shape future pastoral livelihood pathways and other options in the ASALs. The focus on pastoral livelihood vulnerability and risk, alongside opportunities arising from integration into the national economy, is appropriate for pastoral settlements, which continue to face high levels of drought risk and protracted periods of geographical and political marginalization (Devereux 2010).

The main modification that this paper makes to the framework proposed by Little et al. (2001b) is to expand the local response variables to include two additional sets of variables, namely, social relation variables and institution variables.

This approach is relevant to the study area for three reasons. First, this approach recognizes the importance of opportunities arising from improved conditions in service provision, infrastructure and decentralization of governance functions in Kenya as well as corresponding increases in contemporary challenges and risks in pastoralist areas. Second, this approach highlights the important context of specific local level and household variables in the diversification strategies of herders. Finally, this approach emphasizes the critical interaction between socio-economic and environmental sub-systems, which implies that changes in either of the systems influence the state of the other. Thus, this approach supports several competing hypotheses with specific observable consequences that help explain the relationship between opportunities, risks and livelihood diversification in pastoral settlements in the ASALs. In this inquiry we provide an empirical test of the following two hypotheses by satisfactorily testing them against a great variety of data in Isiolo County.

H1. Diversification into non-livestock income activities arises out of the pastoral economy when fundamental change in household mobility permits household members to be separated into sedentary settlements and mobile satellite camps.

$\mathrm{H} 2$. Income diversification is negatively correlated with household dependence on livestock income.

\section{Applied literature: Risk vs. opportunity}

Two broad perspectives have been advanced to explain why rural households with limited livelihood options diversify their income sources. A very popular interpretation suggests that economic diversification is a consequent outcome of the interaction between livelihoods and risks resulting from natural or man-made hazards (or a combination of both) and vulnerable conditions (Deng 2010; Shahbaz 2008; Little et al. 2001a).

Analyses of pastoral diversification along these lines have tended to focus on the livelihood risks driving herders out of pastoralism, where the major concerns have been destitute herders and options outside the livestock economy. Hazards such as droughts, war, and economic shock are portrayed as obstructive and destructive to pastoral herder livelihood assets and 
incomes. Consequently, livelihood diversification, some have argued, is "undertaken to manage risk, cope with shock, or escape from agriculture in stagnation or in secular decline" (Reardon et al. 2007, p. 115) influenced differentially by the nature of risk itself, the location of the household, the wealth and assets available and the access to credit and other risk management options (Deng 2010). In addition, livelihood diversification has been praised for its adaptation to climatic variability (Mortimore and Adams 2001), greater welfare impacts (Ersado 2006) and enhanced productivity (Di Falco and Chavas 2009), among other reasons.

While many researchers agree that livelihood risks constitute a major determinate of diversification, a central criticism of the livelihood risk perspective pertains to the role of historical changes in rural areas and innovations that tend to drive economic diversification even in the absence of livelihood risks. Changes, such as increased access to markets, new technologies such as mobile phones and motorized transport, have a profound influence on economic diversification in rural areas (McPeak and Little 2006). In spite of much criticism, the risk-hazard perspective has inspired a large number of empirical studies (Barrett et al. 2001a, b; McPeak and Barrett 2001) and has informed agricultural risk management strategies.

An alternative perspective, "diversification undertaken for accumulation objective", seeks to explain economic diversification as driven mainly by pull factors (Reardon et al. 2007). Certain features of non-farm/non-livestock economic activities provide diversification incentives. For instance, Lingohr-Wolf shows that a higher return available to rural enterprises is a major pull factor encouraging a shift in employment towards the non-farm sector in rural China (Lingohr-Wolf 2011). The emphasis is on seeing current agricultural productivity challenges as deriving, to a greater extent, from a lack of opportunities in finance, technology and innovation and other opportunities in rural areas. Pull factors such as higher productivity, the power of technology and lower risks are seen as an integral part of sustainable livelihoods (Hussein and Nelson 1998). From this perspective, the market access, higher payoffs and lower risks of no-farm activities allow households to accumulate capital that can increase farm income (Reardon et al. 2007).

Although the debate regarding these two perspectives has already become an issue of discussion along with the status of livelihood diversification in rural Africa, taking livelihood risks (push factors) and opportunity pull factors in isolation is insufficient to address the complexities exhibited by rural livelihoods. As Deng (2010) argues, the literature on diversification has paid little attention to intra-household strategies of households subjected to multiple sources of risk and how these strategies play out within available opportunity pull factors. At the same time, the value of pull factors should be to mitigate livelihood risks. For example, it is likely that increased access to markets, growth in access to microfinance, new technologies such as mobile phones and motorized transport could play such a vital supportive role.

The study area and pastoral livelihood changes in East Africa in general have been the subject of considerable research in recent times, and the bulk of this work has focused on vulnerability to climate change (Paavola 2008; Morton 2007; Luseno et al. 2003), the environmental and economic consequences of pastoral livelihoods (Galvin 2009; Fratkin and Roth 2006) and the patterns of resource conflict, famine and droughts (Meier et al. 2007; Fratkin and Roth 1990; Campbell 1984). Concurrently, there have been studies on the impact of economic and political marginalization in relation to worsening drought emergencies in the region (Raleigh 2010; Doornbos 1993) and the historical and contemporary dynamics of pastoralism (Dalleo 1975).

In addition, there has been an intensification of inquiries on specialization and diversification in pastoral economies, which, for the first time, provide detailed overviews that can be used to make inferences concerning the diversity of the social and economic aspects of pastoral livelihoods (Catley et al. 2013; Bollig et al. 2013). Despite these high-quality and detailed analyses, it remains difficult to resolve current debates over the nature and extent of pastoral livelihood diversification, the success rate of alternative economic activities in a pastoral economy and the relative effect of economic diversification on household resilience to risks and shocks associated with pastoral production. These gaps are compounded by the fact that social change and the socio-economic transformation of pastoral economies are relatively permanent features rather than a state, as observed by Hogg (Hogg 1992), thus making it difficult to relate observed changes in pastoral livelihoods directly to just one or a specific group of livelihood risks or opportunities. Additionally, while most case studies of pastoral livelihood change have utilized the extensive body of livelihood approaches that emphasize household livelihood security as the ultimate goal, the level of detail and specific relevance to risk-averse pastoral livelihoods become far less reliable.

As noted earlier, few studies have investigated the impacts of non-pastoral income on household dependence on pastoral livestock (Little et al. 2001a, b; McPeak and Barrett 2001). Different pastoral wealth groups participate in NPIs for different reasons while at the same time remaining engaged in pastoral production at differing scales. Many opportunities, however, remain to examine the impacts of NPIs on household dependence on 
pastoral livestock. This study seeks to understand the impact of NPIs on household dependence on pastoral livestock in pastoral settlements in Isiolo County, northern Kenya. Furthermore, it seeks to elucidate how NPI is associated with the risks and opportunities available to households and the emerging household livelihood strategies associated with NPIs. Along these lines, this study investigates two research questions:

RQ1. What are the determinants and patterns of household NPIs?

RQ2. What is the impact of household participation in NPIs on its dependence on livestock income? Do NPIs result in a decline in dependence on livestock income?

\section{Study area}

Garba Tula and Kinna are divisional administrative settlements established in the 1960s, and they are 120 and $85 \mathrm{~km}$, respectively, from the county administrative headquarters, Isiolo town. Kulamawe is a remote pastoral settlement outside Garba Tula with dry season water wells and pasture fields. The combined population of the study areas grew from a couple of thousand people in the 1980s to an estimated 40,000 in 2009 (KNBS 2010). The study areas are typical of pastoral settlements in east Africa associated with impoverishment through massive stock losses, government policies and, in some cases, voluntary settlements as pastoralists' interests in education, crop agriculture and trade grew (Fratkin 1991, Nunow 2000, Niamir-Fuller and Turner 1999). Sedentarisation opened the way for reduced mobility of part or entire pastoral households.

This research was conducted by focusing mainly on pastoralists' settlements where households are divided between sedentary settlements and satellite camps. These settlements in Isiolo County provide an interesting location to investigate the livelihood diversification dynamics of pastoral settlements for three main reasons. First, the settlements situated in the northern arid plains of Isiolo County constitute the first pastoralist settlements in the area as a result of their strategic proximity to permanent settlements as well as the dry season grazing pasture lands and water resources. Garba Tula (which translates to "Deep Wells" in the Borana language) forms part of the larger fall-back territories for pastoral herders during the dry season. Second, Kinna's proximity to Isiolo and Meru towns enables easy access to livestock markets and town centres and has become a proximate settlement for pastoralists who sought livestock markets. Most government services are represented in the study areas, notably, the education, health and agriculture departments.

Generally, Isiolo South is arid, with a hot and dry climate, and is inhabited mainly by the Boran pastoral community. Isiolo County is characterized by flat, low-lying plains consisting of the Lorian Swamp in the north and the Daaba and Merti plateaus to the south (Salah 2014). This area is part of a larger rangeland ecosystem that stretches from Meru in the south to the much more arid territories of Marsabit and Samburu in the north.

Characterized by aridity and low annual rainfall of less than $500 \mathrm{~mm}$, the household economy of Isiolo South is primarily dependent on livestock herding on communally- owned natural resources (Salah 2014). The Borana pastoralists are nomadic and herd cattle, sheep, goats and camels. The variability of pasture and water in Isiolo South compels pastoralists to graze their livestock beyond the boundaries of Isiolo County, as is the case with all other pastoral herders in the region (Ontiri and Robinson 2015). Historically, the Borana in the areas around Isiolo County have been highly mobile, migrating across the low-lying plains into neighbouring counties such as Marsabit, Samburu and Wajir.

The Isiolo Borana ${ }^{2}$ pastoralists are a relatively highly mobile population. As with all other pastoral communities, spatial mobility is associated with flexibility and resilience where pastoralists interface with environmental variability and variability in production (van den Brink and Eugenius 2005).

\section{Methods}

\section{Data collection}

To collect quantitative data on household ${ }^{3}$ livelihood activities (both livestock and NPIs), a structured household survey was implemented with a total of 260 households $(n=260)$. The household survey was conducted with households in the three selected pastoral settlements and was intended to help discern a range of issues pertaining to general household demographic data and household livelihood information, including livelihood and income activities; livestock strategies, risks and social exchange networks; and household perceptions and expectations in relation to future livelihoods. Households involved in non-livestock activities were asked some basic questions regarding the scale and intensity of the operation of such activities, the sources of capital for such enterprises and the main uses of the earned income.

Key informant interviews $(n=18)$ and focus group discussions $(n=6)$ were conducted with people knowledgeable on livelihood histories in the area and alternative livelihood pathways undertaken in the region. This category of people included leaders, administrators and community elders. The qualitative data collected was used to (1) access the types and patterns of NPIs and other aspects of livelihood diversification; (2) inform the development of tropical livestock unit (TLU)-based 
wealth ranking from the household survey data; and (3) yield information on the association between NPIs and pastoral livestock livelihoods to facilitate discussions on whether NPIs are deleterious to household dependence on livestock. This method allowed for discussions around drivers of NPIs as well as the risks and opportunities available to households in the study settlements. Participants were selected for their knowledge and participation in either one or both livestock livelihoods and NPIs. Local leaders and Chiefs were enlisted to assist in the identification of key informants. The interviews addressed a range of topics as described in Table 1. All interviews were conducted by the first author with the assistance of a research assistant who also served as a translator.

The data collection strategy, primarily done by FGDs and semi-structured group interviews by employing participatory rural appraisal techniques (Chambers 1994), sought qualitative discussions centred on the broader socio-economic context and the drivers of pastoral diversification into NPI activities in the selected pastoral settlements. However, the data collected provided limited information on the impact of NPIs on livestock income. Therefore, the data collected precluded the clarification of the relationship between NPIs and livestock income. However, the data does provide robust information on the extent to which the respondent households were involved in NPIs and if their engagement in NPIs does affect their dependence on livestock and the direction of that relationship. The household participation in NPIs was done as a matter of necessity and intention confirming the existence of livestock livelihood risks and opportunities outside the livestock sector respectively. First, the households revealed that NPIs primarily occurred in settlements; this means that the fundamental change in the household's mobility status was a key determinant of participation in non-livestock income activities. Second, by design, the study sought to examine the relationship between opportunities outside the livestock sector and household participation in NPIs. The data sought was intended to investigate both the opportunities that drive NPIs as well as the impact of risks related to livestock livelihood in the study area.

\section{Data analysis}

One of the first tasks was to categorize the households surveyed in terms of wealth categories at the time of the study. Previous studies (McCabe 2003; Potkanski 1994;

Table 1 Summary of research methods

\begin{tabular}{|c|c|c|c|}
\hline Method & Sample size & Approach & Purpose \\
\hline Household survey & $\begin{array}{l}260 \text { respondents split among the } \\
\text { three study pastoral settlement sites }\end{array}$ & $\begin{array}{l}\text { Random sampling from the village } \\
\text { household roster obtained from } \\
\text { the village chiefs }\end{array}$ & $\begin{array}{l}\text { The household survey }(n=260) \text { was } \\
\text { conducted with households in the three } \\
\text { selected pastoral settlements and was } \\
\text { intended to help discern a range of issues } \\
\text { pertaining to general household } \\
\text { demographic data and household } \\
\text { livelihood information including livelihood } \\
\text { and income activities; livestock strategies, } \\
\text { risks and social exchange networks; and } \\
\text { household perceptions and expectations in } \\
\text { relation to future livelihoods. Household } \\
\text { involved in non-livestock activities were } \\
\text { asked for some basic questions on scale } \\
\text { and intensity of operation of such activities, } \\
\text { sources of capital for such enterprises and } \\
\text { main uses of earned income. }\end{array}$ \\
\hline
\end{tabular}

Key informant interviews 18 people with particular knowledge of pastoral livelihoods, livelihood dynamics and transition in the area

Focus group discussions

60 (20 from each study site) people drawn from the household survey with knowledge on different livelihood pathways

Analysis of previous studies from the region
Purposive sampling of key knowledgeable informants including key elders in the Borana Dedha, NGOs staff, government officials and extension officers

Purposive sampling of household survey respondents with particular knowledge of key livelihoods issues including pastoralists, traders in livestock and livestock products, petty traders, labourers and people in formal employment

Secondary data from the region on similar livelihood diversification and NPI issues
Test patterns observed in key literature and policy discourse on the determinants and drivers of exit from pastoral livestock livelihoods and the rise of NPI in the study sites

Test patterns and drivers of pastoral diversification into NPI by identifying (a) any significant deviation of the data; (b) key informants interpretation of the patterns and drivers of NPIs and consequences of observed changes; and (c) their perceptions of future drivers and patterns of NPI in the area

Identify (a) key drivers and patterns of pastoral diversification into NPIs and (b) association between NPIs and pastoral livestock livelihoods 
Nduma et al. 2001) have used livestock conversion to tropical livestock units (TLU) per capita ${ }^{4}$ to define wealth categories for pastoral herders. Based on TLU per capita, households were ranked, and the sub-categories listed under wealth were destitute $(<0.5$ TLU), very poor (0.5-1.25 TLU), poor (1.25-2.50 TLU), medium (2.5-5.0 TLU), wealthy (5.0-10.0 TLU) and very wealthy (above 10 TLU) based on (McCabe et al. 2010). Using the household survey data, we ranked households based on their TLU per capita and then corroborated the resultant rankings with key informants. This validation exercise confirmed TLU per capita wealth rankings to be reasonably accurate as has previous PRA studies (Takasaki et al. 2000). In addition, the distribution of the characteristics of households' main livelihood sources in the three study communities was analyzed using the respondents' main source of income, to show the distribution and ranking of household income sources.

Second, we identified the likely association between pastoral household mobility and participation in NPI activities. Related analyses also include household demographics and participation in NPI activities by looking at the household division of labour in different household income activities. To establish the direction of this relationship between household mobility and participation in NPIs, we put all households surveyed into three categories according to their mobility, namely, fully settled, for households where household members are permanently settled; partially settled, for households where members are divided between permanent pastoral settlements (for members not engaged in herding) and satellite camps (for the mobile unit of the household engaged in herding the household livestock); and nomadic, for households where the entire household is mobile (engaged in herding livestock) (Figure 2). Identifying the likely association between differences in household members' income activities for households that are partially settled and nomadic is important as these categories of households have household members divided between permanent pastoral settlements and satellite camps. Key household demographic data analysed to determine participation in NPIs include gender, level of education of the household head and primary livelihood (and the main income source) of the household head.

Third, the extent of household dependence on pastoral livestock income and related activities was examined by comparing what the household considered its main income source against all other sources of income.

\section{Results}

\section{Study site characteristics}

The livelihood diversification literature in pastoral areas has widely recognized that the household labour composition plays a critical role in the participation in and choice of non-farm income. This is particularly true in pastoral societies, where mobility is a critical livelihood factor, such that household labour is an even more prominent factor determining the participation in and choice of non-pastoral income. Therefore, household

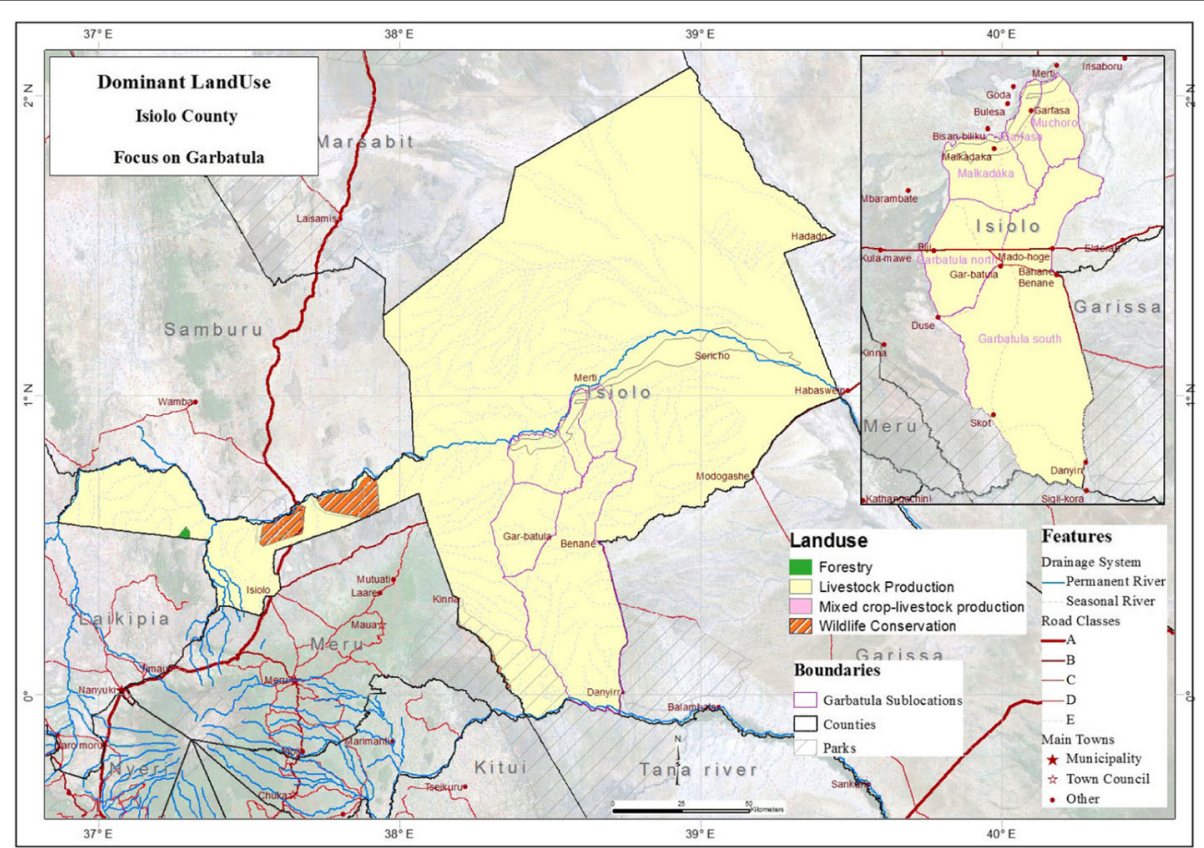

Figure 2 Land use categories in the research sites in Isiolo County, northern Kenya. Source: Centre for Research and Training in ASAL Development (CETRAD) 2008 
mobility status, estimates of household income and its sources and the disaggregation of income between household members in permanent and satellite settlements provide insights into participation in and choice of NPIs.

The study communities exhibited varying asymmetries in their livelihood strategies and the major factors that determine household participation in NPI activities, their performance and their impact on household dependence on livestock. Figure 3 shows the mobility status of households in the three study communities. Garba Tula Township is the administrative centre for Garba Tula, and Kinna is the largest pastoralist settlement among the study communities, while Kulamawe is a smaller pastoralist settlement. As has been widely recognized by other studies of pastoral societies, household mobility has changed significantly in these study communities. All the study communities have a significantly higher number of households that are partially settled - meaning household members are divided between the settlement and satellite camps. A more straightforward effect of reduced household mobility (as opposed to permanent settlement) is the reduction in the number of mobile pastoralists in all the study settlements and hence the rise of NPIs. However, Kulamawe and Kinna also have a fairly equal proportion of households that are permanently settled and partially settled due to the shorter distances to the satellite camps, meaning households have flexibility regarding keeping herds at the settlements and grazing them where the satellite camps are located.

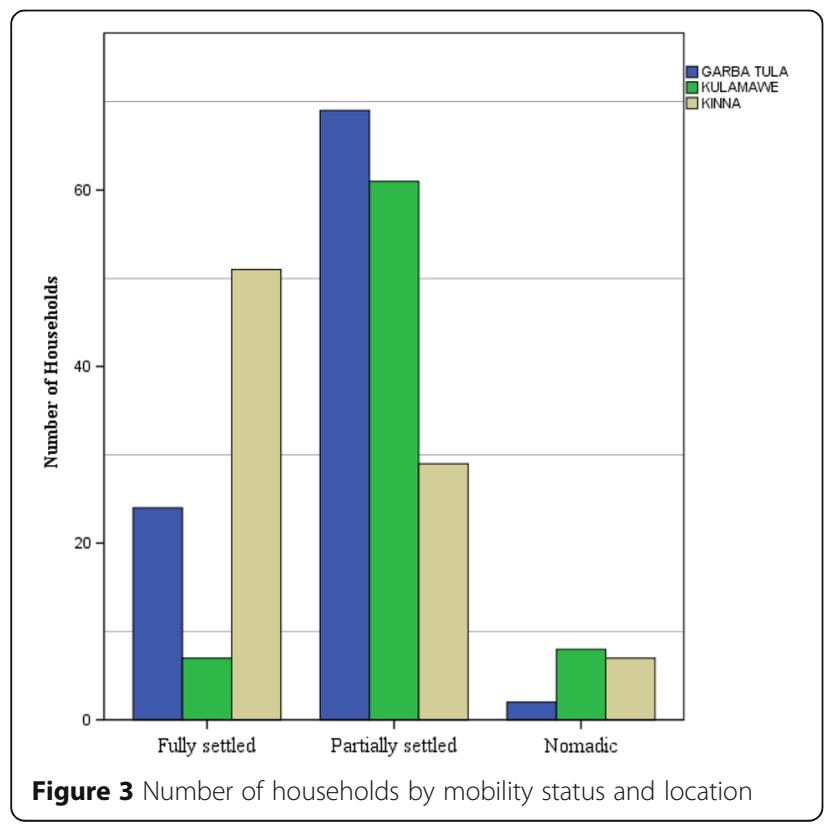

\section{Household livelihood strategies and income}

The prevalence and importance of income diversification for pastoral households can be partly understood by looking at the household livelihood strategies and income sources from the primary income earning activity of the household head. Tables 2 and 3 provide the main sources of household income and the household livelihood strategies, respectively, for the three pastoral settlements studied.

From this perspective, it is evident that livestock herding, i.e. pastoralism, remains a principal source of income for the majority of households in the pastoral settlements studied, with $45 \%$ of household heads declaring that livestock is their principal source of income. Thus, despite the widespread participation in non-pastoral income activities, livestock herding remains prevalent.

\section{Prevalence and distribution of NPIs}

In order to assess household non-pastoral income activities, we examine the composition of household incomes for a definite period through "income recall" and compare them to gauge the proportional contribution of NPIs to the overall household income. Household participation in NPI activities in addition to income derived from the main livelihood was enumerated for the three pastoral settlements. It is clear from Table 1 that while different livelihood options are pursued in the pastoral settlements studied, pastoral herding remains the most important income-earning activity for the majority of households.

A wide range of NPI activities are undertaken in the three studied pastoral settlements; the main activities are illustrated in Table 4.

Petty trade, retail shop activities and casual (non-livestock) labour clearly dominate as the household cash income activities that households engage in, accounting

Table 2 Main income source of household head

\begin{tabular}{lll}
\hline Main income source of household head & Frequency & Percent \\
\hline Herding livestock & 118 & 45.4 \\
Trading in livestock & 20 & 7.7 \\
Casual labour & 28 & 10.8 \\
Gathering and sale of wild & 17 & 6.5 \\
products in (e.g. charcoal/ & & \\
water trading) & 28 & 10.8 \\
Retail shop activities & 12 & 4.6 \\
Trade in livestock products & 32 & 12.3 \\
Petty trading & 4 & 1.5 \\
Wage/salaried employment & 1 & 0.4 \\
Other & 260 & 100.0 \\
\hline Total & & \\
\hline
\end{tabular}


Table 3 Percentage households by livelihood strategy

\begin{tabular}{|c|c|c|c|}
\hline & Garba Tula & Kulamawe & Kinna \\
\hline Undiversified pastoralists & $35 \%(n=34)$ & $50 \%(n=38)$ & $53 \%(n=46)$ \\
\hline Undiversified non-pastoralists & $8 \%(n=8)$ & $7 \%(n=5)$ & $8 \%(n=7)$ \\
\hline Diversified pastoralists + retail shop activities & $18 \%(n=17)$ & $13 \%(n=10)$ & $1 \%(n=6)$ \\
\hline Diversified pastoralists + petty trade & $14 \%(n=14)$ & $13 \%(n=10)$ & $9 \%(n=8)$ \\
\hline Diversified pastoralists + salaried employment & $6 \%(n=6)$ & $1 \%(n=3)$ & $0 \%(n=0)$ \\
\hline Diversified pastoralists + gathering and sale of wild products & $8 \%(n=8)$ & $3 \%(n=2)$ & $11 \%(n=10)$ \\
\hline \multirow[t]{2}{*}{ Diversified pastoralists + casual labour } & $10 \%(n=10)$ & $11 \%(n=8)$ & $11 \%(n=10)$ \\
\hline & 97 & 76 & 87 \\
\hline
\end{tabular}

for $12 \%$ and $11 \%$ respectively. Of all the non-pastoral income activities reported by households, petty trade and casual labour accounted for 16\% and 55\% of households, respectively, after livestock herding (Table 5). Reference to food for work and NGOs supporting micro-business enterprises, especially in the Garba Tula area, can be found in a number of studies on the region (Pantuliano and Wekesa 2008; Gomes 2006). Other field studies have even provided evidence of casual labour as the dominant NPI in northern Kenya, and some have argued that government- and donor-supported programmes are a critical issue in pastoral livelihood exit (Little et al. 2008). The contribution of government and NGO programmes to income diversification in pastoral settlements has implications for the determinants of livelihood diversification.

The data reveal that there is more significant involvement of male-headed households in NPIs than women-headed households ${ }^{5}$ both in terms of prevalence

Table 4 Non-pastoral income activities in the study settlements

\begin{tabular}{ll}
\hline NPI activity & Description of activity \\
\hline Casual labour & Labour for wages both within the settlements \\
& and externally in urban centres including \\
& employment as security guards, construction \\
& and related labour, transportation labour
\end{tabular}

Gathering and sale Mainly firewood, charcoal, honey and gum of wild products Arabica for sale within the settlement and externally

Retail shop activities Retail shop activities in the area include sale of food stuffs, toiletries, tobacco, animal drugs and related goods. Retail shop activities are carried out from a permanent point (shop/kiosk)

Trade in livestock products

Sale of milk, meat and hides. This does not

Petty trading include "herd gate" sales (see Little et al. 2001a, b)

Trading in products (both food and non-food) involving mobility of the trader mainly dealing with clothes, perishable food stuff, animal health products, mobile phones and accessories, simple electronics (torch, radio receivers etc.)

Formal wage employment and involvement in "high value" NPIs. In all the study areas, male household heads have a greater degree of income diversification and are more likely to engage in high value NPIs than female household heads. The results shown in Figure 4 indicate that male-headed households have significantly higher participation in livestock trade, petty trade and retail shop activities. It is apparent that while NPIs are generally available to all households in the study area, female-headed households engage only in a few "low entry-barrier" activities (Reardon et al. 2000), such as the gathering and sale of wild products. This finding is consistent with other studies that have noted discrepancies in the proportion of women with access to potential income sources compared to that of men (Ellis 2000; Coppock 1994b). The survey further suggests that although both male- and female-headed households are represented in all income activities, more male-headed households engage in the sale of livestock products in the study area. While a large number of women still engage in milk trading, there is a large number of men engaging in milk trade. The reason that milk is becoming a "high value

Table 5 Share (\%) of pastoral households' income from different sources

\begin{tabular}{llll}
\hline & GARBA TULA & KULAMAWE & KINNA \\
\hline Herding own livestock & $34(13.1 \%)$ & $38(14.6 \%)$ & $46(17.7 \%)$ \\
Trading in livestock & $8(3.1 \%)$ & $5(1.9 \%)$ & $7(2.7 \%)$ \\
Casual labour & $10(3.8 \%)$ & $8(3.1 \%)$ & $10(3.8 \%)$ \\
$\begin{array}{l}\text { Gathering and sale of } \\
\text { wild products in (e.g. }\end{array}$ & $5(1.9 \%)$ & $2(0.8 \%)$ & $10(3.8 \%)$ \\
charcoal/water trading) & & & \\
Retail shop activities & $17(6.5 \%)$ & $10(3.8 \%)$ & $1(0.4 \%)$ \\
Trade in livestock products & $5(1.9 \%)$ & $2(0.8 \%)$ & $5(1.9 \%)$ \\
Petty trading & $14(5.4 \%)$ & $10(3.8 \%)$ & $8(3.1 \%)$ \\
Wage/salaried employment & $3(1.2 \%)$ & $1(0.4 \%)$ & $0(0.0 \%)$ \\
Other & $1(0.4 \%)$ & $0(0.0 \%)$ & $0(0.0 \%)$ \\
Total & $97(100 \%)$ & $76(100 \%)$ & $87(100 \%)$ \\
\hline
\end{tabular}




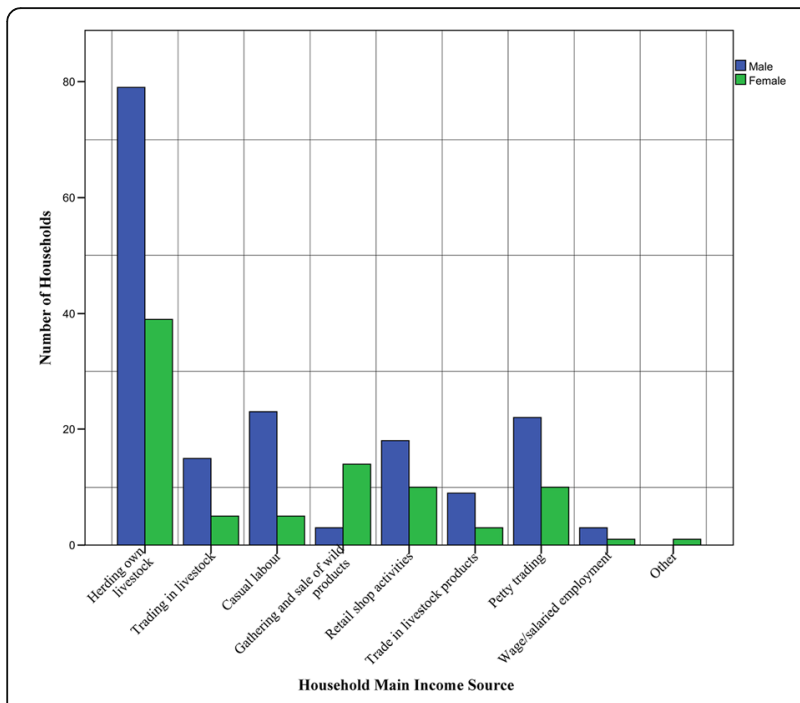

Figure 4 Primary activities of household heads (male and female)

commodity". This point also emphasizes inequalities in participation on NPIs which makes men participate more in high-value commodities (Musinga et al. 2008; Anderson et al. 2012).

Wealth ranking is a critical element in income diversification (Ellis 2000; Little et al. 2001a, b). Each of the households included in our survey were asked to list all their income from different sources and to make a distinction between household income from livestock and incomes from non-livestock sources. Total reported household income from both livestock and non-livestock sources, reported by household, was highest among the very wealthy-ranked households by TLU, making approximately Kshs. 60,000 per year, followed by the wealthy and medium ranked households, at Kshs. 40,000 and Kshs. 25,000, respectively (Figure 4). Overall, poorer households made less than Kshs. 20,000 per year, and their income was mainly derived from non-livestock sources. ${ }^{6}$

There are no significant differences in the level of diversification between the poor and wealthy groups (all households reported income from both livestock and non-livestock sources), but income earnings indicate very different opportunities and levels of earning. In terms of the contribution of income, wealthy households derive a similar proportion of their income from livestock and non-livestock sources. However, this close comparability of proportional contributions from livestock and non-livestock income sources does not carry through to poorer households; destitute, very poor and poor households (defined by TLU owned per person) derive most of their income from livestock. There are both economic and social reasons to explain low earnings from both livestock and non-livestock activities by the poorer households. Among the economic reasons, the high cost of transporting livestock to better markets and engaging in informal non-livestock activities play a dominant role (Little et al. 2001a, b). In summary, poorer households participate less in commercial activities and participate more in subsistence-oriented activities, compared to wealthier households, as suggested by the quantitative differences in their earnings from different activities. As a result, returns from both livestock and non-livestock activities are lower for poorer households (based on TLU), as evidenced by their low incomes. This study has shown a similar pattern in pastoral settlements in Isiolo County, where market access and participation in commercial (as opposed to subsistence) activities constrains poorer households more than their wealthier counterparts.

\section{Determinants of household participation in NPIs in the study area}

Household decisions regarding participation in and choice of NPIs are conditioned by many factors classified broadly by Little et al. as opportunity factors, conditioning factors and local response variables (Little et al. 2001a, b: 406). In Table 6 below, we summarize the pastoral household response to an open-ended question regarding the most important reason why the households started pursuing NPIs. Both opportunity and conditioning variables are represented in the most commonly cited reasons for the decision to participate in NPIs. Prominent opportunity variable factors that were identified include supplementing lost/decreasing income from livestock; compensating for the loss of livestock as a result of drought, conflict and livestock diseases; and avoiding selling livestock to pay for petty expenses, while opportunity factors driving household income diversification include the availability of external support and the influence of early diversifiers. The most striking figure in Table 6, however, is the extremely high share of households diversifying to avoid selling livestock to pay for petty expenses. This finding is somewhat consistent with pastoralists' principal objective of retaining livestock - a critical source and store of wealth and insurance (Bailey et al. 1999), which are important given the

Table 6 Main reason for starting to engage in chosen NPI

\begin{tabular}{lll}
\hline Reasons & Frequency & Percent \\
\hline $\begin{array}{l}\text { Supplement lost/decreasing livestock } \\
\text { income }\end{array}$ & 28 & 10.8 \\
$\begin{array}{l}\text { Availability of household labour not } \\
\text { engaged in livestock herding }\end{array}$ & 48 & 18.5 \\
$\begin{array}{l}\text { Availability of external support } \\
\text { (government, NGO, Chama, relatives) }\end{array}$ & 36 & 13.8 \\
$\begin{array}{l}\text { Influence of early diversifiers (neighbor, } \\
\text { relative, friend) }\end{array}$ & 35 & 13.5 \\
$\begin{array}{l}\text { To avoid selling livestock for petty } \\
\text { expenses }\end{array}$ & 100 & 38.5 \\
Other & 13 & 5.0 \\
Total & 260 & 100.0 \\
\hline
\end{tabular}


significant risk of loss from climatic, conflict and epidemiological shocks.

In addition, there has been a fundamental change in pastoral household mobility, where men and young boys herd livestock in satellite camps away from the "home-base" settlement where women, elder members of the household and young children are based. Sometimes, long distances between the home-base settlements and satellite camps make the distribution of household income hard to manage. Participation in NPIs makes it easier to provide for the household members at the base camp settlement without having to sell livestock in the satellite camps; furthermore, the livestock might be located in multiple camps located at long distances from each other depending on the season.

\section{The larger context of pastoral income diversification}

Key informants revealed the contextual environmental and policy drivers in northern Kenya more broadly that have played a role in household participation in NPIs. First, drought and other climatic shocks that constitute the major inhibiting factors in pastoral livestock production have increased in intensity and frequency, leading to a notable mismatch between the human and livestock populations. Hence, the push factor of "too many people, too few livestock" (Sandford 2006) has been responsible for herders seeking alternative sources of income, mainly in the informal sector in major towns and urban centres. Loss of livestock to drought and other shocks has provided opportunities for pastoral households seeking options outside of the livestock economy (Fratkin and Roth 1990).

Second, renewed policy and investment interest in the pastoral drylands by the Kenyan government and external donors has resulted in qualitative improvements to infrastructure, communications and access to markets (Mogaka 2006; Kihiu and Amuakwa-Mensah 2016) that had been previously inaccessible due to the high costs occasioned by their inaccessibility, insecurity and general lack of incentives (Schilling et al. 2012; Mude et al. 2009). The combination of improved policy and infrastructure development has supported an improved business environment and hence provided pull factors for the growth of NPIs.

\section{Discussion}

In examining the outcomes of household income diversification for pastoralists in the study areas, we focused on the patterns and drivers of NPIs and their impact on household dependence on livestock income. Pastoral households in the study areas do not have a wide range of income opportunities outside of livestock herding, and the available NPI options are highly related to pastoral livestock production (and related household mobility status), growth of the informal sector, and increased external investment into the region. Diversification in these pastoral areas is mainly into small-scale informal market niches for livestock products and petty trading serving the sedentary pastoral population and in rare cases a very small number of urban clients. As a result, especially for households in the poorer wealth TLU categories, diversification is not a channel for wealth accumulation but rather an important element in household subsistence in the pastoral settlements studied while herds are away in the satellite camps during dry seasons. These findings are in accordance with those of Little et al. (1994) in which no association between milk trading and the accumulation of investable surplus were found in southern Somalia.

Generally, change in mobility, where one part of the household stays in a pastoral settlement while the other part manages the herds at satellite camps, seems to have been on the increase in the study areas, similar to most pastoral settlements in East Africa. This finding is by the literature on the diversification of pastoral livelihoods because pastoral sedentarisation is associated with, among other things, increased engagement in diverse income activities (Fratkin and Roth 2006; Ensminger 1992). In the study area, the mobility of the entire herder household has become problematic - especially considering the broader goals of education and the need to claim public services, which are not as flexible as pastoral livelihood strategies. Pastoral herders have largely settled as a result of state-supported fragmentation and the loss of the rangelands (Abbink et al. 2014) as well as economic, political, demographic and environmental changes (Fratkin and Roth 2006). Sedentarisation is nevertheless related to long-term change in household mobility and the related household division of labour, as household members become dispersed between sedentary settlements and satellite herder camps. This fundamental change in household mobility, especially having women in the settlements who provide support to the herders in the satellite camps through the sale of livestock products such as milk, can be considered a long-term driver of income diversification. Politically sanctioned loss of pastoral rangelands to make way for other land uses such as wildlife conservancies and large scale infrastructure projects has been witnessed in Isiolo County leading to displacement from strategic rangeland resources (Roba 2014; Boye et. al 2011; Markakis 1999).

Second, as pastoral households slowly but steadily became sedentary in pastoral settlements such as those in Isiolo County, along with other factors such as education, public services and integration into national markets, there arises a growing prospect of the diversification of income and consequently the reduced dependence on income from the mobile unit of the household. Generally, the endurance of mobility among herder households, despite socio-economic and political 
changes (Schmidt and Pearson 2016; Evers et al. 2013), shows the long-term inability of most herder households to fully support the sedentary unit of the household. One of the most important factors regarding the emergence of pastoral settlements in northern Kenya, and the study area in particular, was the increase in the intensity and frequency of droughts in the 1980s and 1990s (Aklilu and Wekesa 2002). The succession of droughts during this period brought intense humanitarian and development programmes (Fratkin 1991; Fratkin and Roth 2006) into pastoral areas as a response to the ravaging drought and associated humanitarian emergency. Our findings indicate that drought risks have been a driver of the growth of partially settled households (household members divided between sedentary settlements and satellite camps) in Isiolo County, and by extension, they have been a major contributor to the growing income diversification trend in the area. Remittance flows from livestock sales in satellite camps might not be reliably speedy sources of income for the sedentary unit of the households for petty expenses. From key informants and focus group discussions, we found a strong correlation between the distance of the satellite camps from settlements and the related difficulty of transmitting remittances from livestock sales and a reliance on NPIs.

Third, complementarity to pastoral livestock production appears to significantly influence household choice regarding whether to participate in non-livestock income activities. The result of this study reveals that the diversification of incomes complementary to pastoral livestock production in pastoral settlements is occurring on two fronts: (1) diversification in the form of trading in livestock (influenced by the development of markets for humanitarian de-stocking programmes) and (2) diversification in the form of trading in livestock products to respond to opportunities arising from expanding urban environments and market centres. Under this system, diversification into "easy income" non-livestock activities is not only supported through livestock assets but also pursued to enhance complementarities with livestock production. This finding may imply that income diversification - as opposed to exiting out of the pastoral livelihood - is attractive and that those engaged in it are mainly incentivized by opportunities within the livestock economy itself, which is enhanced by the growing populations in pastoral settlements. In this case, one may argue that income diversification in pastoral settlements is practiced more as a risk management strategy than a wealth accumulation strategy.

Finally, our examination of the three pastoral settlements suggest that the key to understanding whether NPI activities are deleterious to household dependence on livestock lies in understanding household level strategies with respect to the composition and choice of income activities. There is considerable variation in household strategies in the area, but livestock herding seems to be the common base livelihood reported across all study communities. While NPI activities thus play an important role in the constitution of household income, it seems unlikely that NPIs will replace livestock as the base livelihood - at least for the wealthier categories of households (based on TLU).

Several findings from the case study are evident here. First, livestock seems to be a significant source of household income for all households and especially for the wealthier categories of households as shown in Figure 5. Second, as Table 6 illustrates, the main reason that households engage in NPIs is to minimize the selling of livestock. Livestock wealth accumulation is regarded as a rational household level risk management strategy (McPeak 2005). Third, wealthier households reporting higher incomes from livestock also engage more in NPIs. Therefore, some households in the study settlements seem to be combining livestock herding with NPIs as additional accumulation strategies and investment channels as opportunities emerge in pastoral settlements. These accumulation strategies seem to be a general trend among pastoral societies in the region (McCabe et al. 2014; Berhanu et al. 2007; Homewood et al. 2006).

\section{Conclusions}

This study set out to identify the patterns and determinants of household income diversification in pastoral settlements in Isiolo County and to determine the impact of non-pastoral income activities on household dependence on pastoral livestock income. Using Little's earlier framework (Little et al. 2001a, b), to study the income diversification of pastoralists, we hypothesized that (i) diversification into non-livestock income activities

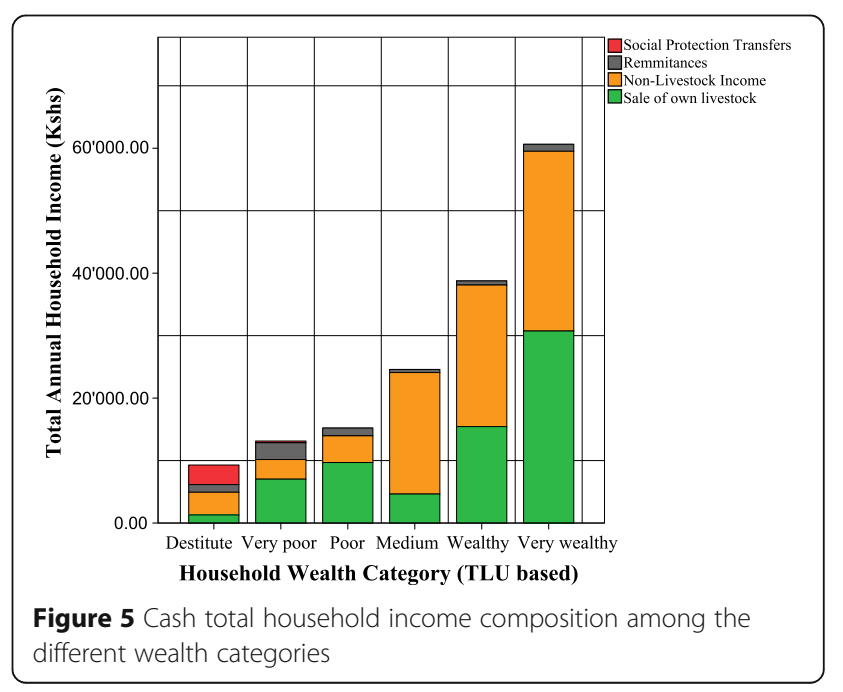


arises out of a pastoral economy when fundamental household mobility change permits household members to be separated into sedentary settlements and mobile satellite camps and (ii) income diversification is negatively correlated to household dependence on livestock income.

We found evidence that among the study area pastoral households, the availability of working age family labour not engaged in livestock herding (particularly the presence of working age women and men) was found to be the most important pull factor towards household participation in NPIs. The growth of pastoral settlements around service centres and water points has encouraged family labour not involved in herding to be fairly sedentary, which is a factor that encourages income activities to supplement pastoral livestock income. NPI activities pursued by households in Isiolo County are all in the informal sector, where capital outlay and skill requirements are low. Petty trading, casual non-livestock labour and retail shop activities constitute the bulk of NPIs that pastoralist households in the Isiolo County settlements engage in. NPIs are mainly used to supplement household pastoral livestock income and to provide for the sedentary part of the pastoral household - which is emphasized by respondents' statements that they wished to "avoid selling livestock for petty expenses". We also found evidence that despite the fact that income diversification is a popular livelihood strategy in pastoral settlements, livestock herding remains a critical livelihood component in the context of the ASALs. Generally, pastoral household members residing in pastoral settlements - mainly women and children - as a result of fundamental change in household mobility tend to engage in non-livestock and livestock product income-generating activities, while the young men herd livestock in the satellite camps. While this differentiation in the economic roles of household members improves household income, it points also to the fact that the reliance and dependency on livestock is not in any way reduced. The evidence indirectly suggests that households that engage in non-livestock income activities are unlikely to exit pastoral herding.

We conclude that the emergence of income diversification among pastoral households is only a short-term strategy designed to bring relief from immediate risks to the household members in the settlements who do not have access to key livestock assets. This is a practice that is particularly used by destitute pastoral households that are seeking alternatives to replenish lost livestock assets and incomes. However, income diversification cannot be sustained without the security and support of the base livestock livelihood. The underlying and long-term structural patterns of income diversification observed in this study include complementarity to the base livestock livelihood. Engaging in NPIs is therefore a quest to adapt to the livestock livelihood risks associated with change in household mobility for the less-wealthy households, rather than a wealth accumulation strategy associated with optimizing opportunities. More broadly, the nature and patterns of income diversification in pastoral settlements indicate the need for development interventions that are responsive to these dynamics.

\section{Endnotes}

${ }^{1}$ The process of pastoralists sedentarisation in east Africa, and northern Kenya in particular, has created diversity of human settlements. The study region is characterized by (1) permanent/semi-permanent human dwellings, usually around administrative functions, education and health facilities; and, (2) satellite camps used during the dry season and set up away from the permanent settlements. For detailed review on the region see (Fratkin and Roth 2006; Fratkin 2001; Hogg 1980)

${ }^{2}$ Isiolo Boran, are also referred to as Waso Boran, are a mobile pastoralist group with cattle as their mainstay of economy. A typical Boran settlement in Isiolo County consists of a grouping of permanent homesteads often linked by kinship or marriage. For a detailed description see (Dahl 1979)

${ }^{3}$ Following ICRISAT definition as quoted in (Udry 1996) "household" is defined in the context of this paper "as the smallest group of persons usually, but not exclusively kin related who form a more or less independent production and consumption unit". The emphasis is on an independent production unit whereby household members acknowledge the authority of one person as head of household whether that person lives with the rest of the household members or not.

${ }^{4}$ Many previous studies in the region have used Tropical Livestock Unit (TLU) as a measure of wealth in pastoral economies. TLU per capita is obtained by dividing the total household TLU with the total number of household members (Fratkin and Roth 2006)

${ }^{5}$ Within the Waso Boran community, men are the heads of the household and make major household decisions relating to production and disposal of livestock (Coppock 1994a). However, in polygamous households wives may not be co-resident in the same homestead or even locality. The study area included female-headed households as separate units with livestock assets - usually a subset of the larger herd of the husband - but an independent household within the definition of the paper. For example see (Randall et al. 2011; Homewood et al. 2009)

${ }^{6} \mathrm{Kshs} / \mathrm{USD}$ rates at $100 \mathrm{Ksh}$ for $1 \mathrm{USD}$ 


\section{Author's contribution}

The author read and approved the final manuscript.

\section{Competing interests}

The author declares that he has no competing interests.

\section{Publisher's Note}

Springer Nature remains neutral with regard to jurisdictional claims in published maps and institutional affiliations.

Received: 18 October 2017 Accepted: 15 March 2018 Published online: 20 July 2018

\section{References}

Abbink, Jon, Kelly Askew, D. Feyissa Dori, Elliot Fratkin, Echi Christina Gabbert, John Galaty, Shauna LaTosky, Jean Lydall, Hussein A. Mahmoud, and John Markakis. 2014. Lands of the future: Transforming pastoral lands and livelihoods in eastern Africa. Halle: Max Planck Institute for Social Anthropology Working Papers Working Paper No. 154.

Aklilu, Yacob, and Mike Wekesa. 2002. Drought, livestock and livelihoods: lessons from the 1999-2001 emergency response in the pastoral sector in Kenya: Overseas Development Institute (ODI). Humanitarian practice network (HPN).

Anderson, David M., Hannah Elliott, Hassan Hussein Kochore, and Emma Lochery. 2012. Camel herders, middlewomen, and urban milk bars: The commodification of camel milk in Kenya. Journal of Eastern African Studies 6 (3): 383-404.

Bailey, DeeVon, Christopher B. Barrett, Peter D. Little, and Francis Chabari. 1999. Livestock markets and risk management among East African pastoralists: A review and research agenda. Economic Research Institute Study Papers Paper 170

Barrett, Christopher B., Mesfin Bezuneh Clark, Daniel C. Clay, and Thomas Reardon. 2005. Heterogeneous constraints, incentives and income diversification strategies in rural Africa. Quarterly Journal of International Agriculture 44 (1): 37-60.

Barrett, Christopher B., Thomas Reardon, and Patrick Webb. 2001a. Nonfarm income diversification and household livelihood strategies in rural Africa: Concepts, dynamics, and policy implications. Food Policy 26 (4): 315-331.

Barrett, Christopher, Kevin Smith, and Paul Box. 2001b. Not necessarily in the same boat: Heterogeneous risk assessment among East African pastoralists. Journal of Development Studies 37 (5): 1-30.

Berhanu, Wassie, David Colman, and Bichaka Fayissa. 2007. Diversification and livelihood sustainability in a semi-arid environment: A case study from southern Ethiopia. The Journal of Development Studies 43 (5): 871-889.

Blackwell, P.J. 2010. East Africa's pastoralist emergency: Is climate change the straw that breaks the camel's back? Third World Quarterly 31 (8): 1321-1338.

Bollig, Michael, Michael Schnegg, and Hans-Peter Wotzka. 2013. Pastoralism in Africa: Past, present and future. Berghahn Books.

Boye et al. 2011. Competing claims and contested boundaries: legitimating land rights in Isiolo District, Northern Kenya. Africa Spectrum 99-124.

Campbell, David J. 1984. Response to drought among farmers and herders in southern Kajiado District, Kenya. Human Ecology 12 (1): 35-64.

Carswell, Grace. 2002. Livelihood diversification: Increasing in importance or increasingly recognized? Evidence from southern Ethiopia. Journal of International Development 14 (6): 789-804.

Catley, Andy, Jeremy Lind, and lan Scoones. 2013. Pastoralism and development in Africa: Dynamic change at the margins. Routledge.

Chambers, Robert. 1994. The origins and practice of participatory rural appraisal. World Development 22 (7): 953-969.

Chantarat, Sommarat, Andrew G. Mude, Christopher B. Barrett, and Michael R. Carter. 2013. Designing index-based livestock insurance for managing asset risk in northern Kenya. Journal of Risk and Insurance 80 (1): 205-237.

Chimhowu, Admos, and David Hulme. 2006. Livelihood dynamics in planned and spontaneous resettlement in Zimbabwe: Converging and vulnerable. World Development 34 (4): 728-750.

Coppock, D. Layne. 2016. Pastoral system dynamics and environmental change on Ethiopia's north-central Borana Plateau-influences of livestock development and policy. In The end of desertification? 327-362. Springer.

Coppock, David Layne. 1994a. The Borana plateau of southern Ethiopia: Synthesis of pastoral research, development, and change, 1980-91. Vol. 5: ILRI (aka ILCA and ILRAD)

Coppock, David Layne. 1994b. The Borana plateau of southern Ethiopia: Synthesis of pastoral research, development, and change, 1980-91: ILRI (aka ILCA and ILRAD).
Coppock, David Layne, Brien E Norton, Bedasa Eba, Jaldesa Doyo, Demisachew Tadele, Dereje Teshome, Ajebush Defar, and Seyoum Tezera. 2015. Enclosures for rehabilitating pond catchments and implications for grazing management on the Borana Plateau.

Dahl, Gudrun. 1979. Suffering grass: Subsistence and society of Waso Borana. Stockholm University.

Dalleo, Peter Thomas. 1975. Trade and Pastoralism: Economic factors in the history of the Somali of northeastern Kenya, 1892-1948.

Davies, Susanna. 1993. Are coping strategies a cop out? IDS Bulletin 24 (4): 60-72.

Deng, Luka Biong. 2010. Livelihood diversification and civil war: Dinka communities in Sudan's civil war. Journal of Eastern African Studies 4 (3): 381-399.

Desta, Solomon, and D. Layne Coppock. 2004. Pastoralism under pressure: Tracking system change in southern Ethiopia. Human Ecology 32 (4): 465-486.

Devereux, Stephen. 2010. Better marginalised than incorporated? Pastoralist livelihoods in Somali Region, Ethiopia. European Journal of Development Research 22 (5): 678-695.

Di Falco, Salvatore, and Jean-Paul Chavas. 2009. On crop biodiversity, risk exposure, and food security in the highlands of Ethiopia. American Journal of Agricultural Economics 91 (3): 599-611.

Doornbos, Martin. 1993. Pasture and polis: The roots of political marginalization of Somali pastoralism. In Conflict and the decline of pastoralism in the Horn of Africa, 100-121.

Ellis, Frank. 1998. Household strategies and rural livelihood diversification. The Journal of Development Studies 35 (1): 1-38.

Ellis, Frank. 2000. The determinants of rural livelihood diversification in developing countries. Journal of Agricultural Economics 51 (2): 289-302.

Ellis, Frank. 2005. Small farms, livelihood diversification, and rural-urban transitions: Strategic issues in Sub-Saharan Africa. The future of small farms 135.

Ensminger, Jean. 1992. Making a market: The institutional transformation of an African society. Cambridge University Press.

Ensminger, Jean, and Andrew Rutten. 1991. The political economy of changing property rights: Dismantling a pastoral commons. American Ethnologist 18 (4): 683-699.

Ersado, Lire. 2006. Income diversification in Zimbabwe: Welfare implications from urban and rural areas. Vol. 3964: World Bank Publications.

Evers, Sandra, Caroline Seagle, and Froukje Krijtenburg. 2013. Africa for sale?: Positioning the state, land and society in foreign large-scale land acquisitions in Africa. Brill.

Fratkin, E.M. 2013. Seeking alternative livelihoods in pastoral areas, Pastoralism and development in Africa: Dynamic change at the margins New York, 197-205. Routledge.

Fratkin, Elliot. 1991. Surviving drought and development: Ariaal pastoralists of northern Kenya. Westview Press.

Fratkin, Elliot. 1992. Drought and development in Marsabit District, Kenya. Disasters 16 (2): 119-130.

Fratkin, Elliot. 2001. East African pastoralism in transition: Maasai, Boran, and Rendille cases. African Studies Review 44 (3): 1-25.

Fratkin, Elliot, and Robin Mearns. 2003. Sustainability and pastoral livelihoods: Lessons from East African Maasai and Mongolia. Human Organization 62 (2): $112-122$

Fratkin, Elliot, and Eric Abella Roth. 1990. Drought and economic differentiation among Ariaal pastoralists of Kenya. Human Ecology 18 (4): 385-402.

Fratkin, Elliot, and Eric Abella Roth. 2006. As pastoralists settle: Social, health, and economic consequences of the pastoral sedentarization in Marsabit District, Kenya. Vol. 1: Springer Science \& Business Media.

Galvin, Kathleen A. 2009. Transitions: Pastoralists living with change. Annual Review of Anthropology 38: 185-198. https://doi.org/10.1146/annurev-anthro091908-164442.

Galvin, Kathleen A., Tyler A. Beeton, Randall B. Boone, and Shauna B. BurnSilver. 2015. Nutritional status of Maasai pastoralists under change. Human Ecology 43 (3): 411-424.

Galvin, Kathleen A., D. Layne Coppock, Paul W. Leslie, E. Fratkin, and E.A. Roth. 1994. Diet, nutrition, and the pastoral strategy, African pastoralist systems: An integrated approach, 113-132.

Gomes, Nathalie. 2006. Access to water, pastoral resource management and pastoralists' livelihoods: Lessons learned from water development in selected areas of eastern Africa (Kenya, Ethiopia, Somalia). FAO LSP WP 26.

Headey, Derek, Alemayehu Seyoum Taffesse, and Liangzhi You. 2012. Enhancing resilience in the Horn of Africa. IFPRI discussion paper 01176. Washington, DC: International Food Policy Research Institute. https://ideas.repec.org/p/fpr/ ifprid/1176.html. 
Hesse, Ced. 2006. Pastoralism: Drylands' invisible asset?: Developing a framework for assessing the value of pastoralism in East Africa. lied.

Hogg, Richard. 1980. Pastoralism and impoverishment: The case of the Isiolo Boran of northern Kenya. Disasters 4 (3): 299-310.

Hogg, Richard. 1992. Should pastoralism continue as a way of life? Disasters 16 (2): 131-137

Homewood, K, Ernestina Coast, S Kiruswa, S Serneels, M Thompson, and P Trench. 2006. Maasai pastoralists: Diversification and poverty.

Homewood, Katherine, Patti Kristjanson, and Pippa Trench. 2009. Staying Maasai? Livelihoods, conservation and development in East African rangelands. Vol. 5. Springer.

Hussein, Karim, and John Nelson. 1998. Sustainable livelihoods and livelihood diversification.

Kihiu, Evelyne Nyathira, and Franklin Amuakwa-Mensah. 2016. Improving access to livestock markets for sustainable rangeland management, 215. ZEF-Discussion Papers on Development Policy.

KNBS. 2010. The 2009 Kenya population and housing census. Nairobi: Kenya National Bureau of Statistics.

Lambin, Eric F., Helmut J. Geist, and Erika Lepers. 2003. Dynamics of land-use and land-cover change in tropical regions. Annual Review of Environment and Resources 28 (1): 205-241.

Lingohr-Wolf, Susanne. 2011. Industrialisation and rural livelihoods in China: Agricultural processing in Sichuan. Vol. 53: Routledge.

Little, Peter, Abdillahi Aboud, and Clement Lenachuru. 2009. Can formal education reduce risks for drought-prone pastoralists?: A case study from Baringo District, Kenya. Human Organization 68 (2): 154-165.

Little, Peter D., E. Fratkin, K.A. Galvin, and E.A. Roth. 1994. Maidens and milk markets: The sociology of dairy marketing in southern Somalia, African pastoralist systems: An integrated approach, 165-184.

Little, Peter D., Hussein Mahmoud, and D. Layne Coppock. 2001. When deserts flood: Risk management and climatic processes among East African pastoralists. Climate Research 19 (2): 149-159.

Little, Peter D., John McPeak, Christopher B. Barrett, and Patti Kristjanson. 2008. Challenging orthodoxies: Understanding poverty in pastoral areas of East Africa. Development and Change 39 (4): 587-611.

Little, Peter D., Kevin Smith, Barbara A. Cellarius, D. Layne Coppock, and Christopher Barrett. 2001. Avoiding disaster: Diversification and risk management among East African herders. Development and Change 32 (3): 401-433.

Luseno, Winnie K., John G. McPeak, Christopher B. Barrett, Peter D. Little, and Getachew Gebru. 2003. Assessing the value of climate forecast information for pastoralists: Evidence from Southern Ethiopia and Northern Kenya. World Development 31 (9): 1477-1494.

Markakis, John. 1999. Briefing: Pastoralists \& Politicians in Kenya. Review of African Political Economy. 26 (80): 293-96.

McCabe, J., Nicole Smith, Paul Leslie, and Amy Telligman. 2014. Livelihood diversification through migration among a pastoral people: Contrasting case studies of Maasai in Northern Tanzania. Human Organization 73 (4): 389-400.

McCabe, J. Terrence. 2003. Sustainability and livelihood diversification among the Maasai of northern Tanzania. Human Organization 62 (2): 100-111.

McCabe, J. Terrence, Paul W. Leslie, and Laura DeLuca. 2010. Adopting cultivation to remain pastoralists: The diversification of Maasai livelihoods in northern Tanzania. Human Ecology 38 (3): 321-334.

McPeak, John. 2005. Individual and collective rationality in pastoral production: Evidence from northern Kenya. Human Ecology 33 (2): 171-197.

McPeak, John G., and Christopher B. Barrett. 2001. Differential risk exposure and stochastic poverty traps among East African pastoralists. American Journal of Agricultural Economics 83 (3): 674-679.

McPeak, John G., and Peter D. Little. 2006. Pastoral livestock marketing in eastern Africa: Research and policy challenges. Intermediate Technology Publications Ltd.

Meier, Patrick, Doug Bond, and Joe Bond. 2007. Environmental influences on pastoral conflict in the Horn of Africa. Political Geography 26 (6): 716-735.

Mogaka, Hezron. 2006. Climate variability and water resources degradation in Kenya: Improving water resources development and management. Vol. 69: World Bank Publications.

Mortimore, Michael J., and William M. Adams. 2001. Farmer adaptation, change and 'crisis' in the Sahel. Global Environmental Change 11 (1): 49-57.

Morton, John F. 2007. The impact of climate change on smallholder and subsistence agriculture. Proceedings of the National Academy of Sciences 104 (50): 19680-19685.

Mude, Andrew, Christopher B Barrett, Michael R Carter, Sommarat Chantarat, Munenobu Ikegami, and John G McPeak. 2009. Index based livestock insurance for northern Kenya's arid and semi-arid lands: The Marsabit pilot Available at SSRN 1844758.

Musinga, Muli, David Kimenye, and Peter Kivolonzi. 2008. The camel milk industry in Kenya. Results of a study commissioned by SNV to explore the potential of camel milk from Isiolo District to access sustainable formal markets.

Nduma, Immaculate, Patti Kristjanson, and John McPeak. 2001. Diversity in income-generating activities for sedentarized pastoral women in northern Kenya. Human Organization 60 (4): 319-325.

Niamir-Fuller, Maryam, and Matthew D. Turner. 1999. A review of recent literature on pastoralism and transhumance in Africa. In Managing mobility in African rangelands: The legitimization of transhumance, ed. Maryam Niamir-Fuller, 1846. London: Intermediate Technology Publication.

Nunow, A. 2000. Pastoralists and markets: Livestock commercialisation and food security in north-eastern Kenya. PhD, University of Amsterdam.

Nyberg, Gert, Per Knutsson, Madelene Ostwald, Ingrid Öborn, Ewa Wredle, David Jakinda Otieno, Stephen Mureithi, Peter Mwangi, Mohammed Y. Said, and Magnus Jirström. 2015. Enclosures in West Pokot, Kenya: Transforming land, livestock and livelihoods in drylands. Pastoralism 5 (1): 1-12.

Ontiri, EM, and LW Robinson. 2015. Landscape management and governance, Garba Tula, Isiolo, Kenya. ILRI Project Report. Nairobi.

Paavola, Jouni. 2008. Livelihoods, vulnerability and adaptation to climate change in Morogoro, Tanzania. Environmental Science \& Policy 11 (7): 642-654.

Pantuliano, Sara, and Mike Wekesa. 2008. Improving drought response in pastoral regions of Ethiopia.

Potkanski, Tomasz.1994. Property concepts, herding patterns and management of natural resources among the Ngorongoro and Salei Maasai of Tanzania.

Raleigh, Clionadh. 2010. Political marginalization, climate change, and conflict in African Sahel states. International Studies Review 12 (1): 69-86.

Randall, Sara, Ernestina Coast, and Tiziana Leone. 2011. Cultural constructions of the concept of household in sample surveys. Population Studies 65 (2): 217-229.

Reardon, Thomas, Julio Berdegué, Christopher B. Barrett, and Kostas Stamoulis. 2007. Household income diversification into rural nonfarm activities. In Transforming the rural nonfarm economy: Opportunities and threats in the developing world, ed. Steven Haggblade, Peter B.R. Hazell, and Thomas Reardon, 115-140. Baltimore: The John Hopkins University Press.

Reardon, Thomas, J. Edward Taylor, Kostas Stamoulis, Peter Lanjouw, and Arsenio Balisacan. 2000. Effects of non-farm employment on rural income inequality in developing countries: An investment perspective. Journal of Agricultural Economics 51 (2): 266-288.

Roba, Sharamo. 2014. The politics of pastoral violence: a case study of Isiolo County, Northern Kenya. Future Agricultures Consortium Working Paper 95.

Salah, Yasin Mahadi S. 2014. The role of indigenous gums and resins in pastoralists' livelihood security and climate change adaptation in Garba Tula area of northern Kenya. Early career fellowship Programme.

Sandford, Stephen. 2006. Too many people, too few livestock: The crisis affecting pastoralists in the greater Horn of Africa, Future Agricultures Consortium debate. Brighton: Institute of Development Studies, University of Sussex.

Schilling, Janpeter, Francis E.O. Opiyo, and Jürgen Scheffran. 2012. Raiding pastoral livelihoods: Motives and effects of violent conflict in north-western Kenya. Pastoralism: Research, Policy and Practice 2 (1): 1.

Schmidt, Matthias, and Olivia Pearson. 2016. Pastoral livelihoods under pressure: Ecological, political and socioeconomic transitions in Afar (Ethiopia). Journal of Arid Environments 124: 22-30

Shahbaz, Babar. 2008. Risk, vulnerability and sustainable livelihoods: Insights from Northwest Pakistan. Sustainable Development Policy Institute.

Smith, Davd Rider, Ann Gordon, Kate Meadows, and Karen Zwick. 2001. Livelihood diversification in Uganda: Patterns and determinants of change across two rural districts. Food Policy 26 (4): 421-435.

Speranza, Chinwe Ifejika, Boniface Kiteme, and Urs Wiesmann. 2008. Droughts and famines: The underlying factors and the causal links among agro-pastoral households in semi-arid Makueni district, Kenya. Global Environmental Change 18 (1): 220-233

Takasaki, Yoshito, Bradford L. Barham, and Oliver T. Coomes. 2000. Rapid rural appraisal in humid tropical forests: An asset possession-based approach and validation methods for wealth assessment among forest peasant households. World Development 28 (11): 1961-1977.

Udry, Christopher. 1996. Gender, agricultural production, and the theory of the household. Journal of Political Economy 104 (5): 1010-1046.

van den Brink, and Rogerius Johannes Eugenius. 2005. Consensus, confusion, and controversy: Selected land reform issues in Sub-Saharan Africa. World Bank Publications. 